\title{
FACTORS AFFECTING ABORTION AND STILLBIRTH AND THEIR EFFECTS ON THE SUBSEQUENT REPRODUCTIVE PERFORMANCE OF COWS UNDER EGYPTIAN CONDITIONS
}

\author{
Ali, M. A. E.*and Safaa S. Sanad \\ Animal Production Research Institute, Agriculture Research Center, \\ Dokki, Giza, Egypt \\ *E-mail: drmamdouh ali@yahoo.com
}

Key Words: abortion, stillbirth, reproductive performance, cows

\begin{abstract}
Abortion and stillbirth are serious problems in cattle breeding, from both economic and animal management standpoints. This study aimed to determine the factors that affect the occurrence of abortion and stillbirth as well as to investigate their effects on the subsequent reproductive performances under Egyptian conditions. The total number of records used in this study was 2098 records. The results showed that the overall incidence of abortion and stillbirth were 3.77 and $5.05 \%$, respectively. Logistical regression analysis revealed that the season and cow parity were the important risk factor for the occurrence of abortion. While cow breed, the season, and cow parity were the important risk factor for the occurrence of stillbirth. The odds ratio showed that the likelihood of occurrence of abortion in cows during the summer was significantly increased $(P=0.024)$ compared to the spring. Also, cows with a parity of 3 or higher were significantly related $(P=0.011)$ to the occurrence of abortion compared to the cows with first parity. In addition, the odds ratio showed that the likelihood of incidence of stillbirth in Friesian cows was increased $(P=0.001)$ by 2.89 times compared to crossbred cows. The summer season recorded the highest incidence of stillbirth compared to the other seasons. The cows parity was significantly $(P<0.05)$ associated with the incidence of stillbirth, cows had $1^{\text {st }}$ parity was higher than that of $3^{\text {rd }}$ or higher parities. Cows had significantly longer days $(P<0.05)$ to the first service, days open and calving interval $(83.9,138.9$, and 432.7 days, respectively) after abortions and (126.5, 182.9, and 478.0 days, respectively) after stillbirths, compared with those that had normal calving $(75.1,109.4$, and 403.2 days, respectively).
\end{abstract}

\section{INTRODUCTION}

Abortion and stillbirth are important functional traits in the breeding of cattle, from both animal management and economic aspects. Abortion in cows is generally defined as the death of the fetus between 42 and 260 days of pregnancy (Peter, 2000; El-Tarabany, 2015). It is a limiting factor for the animal business, as it reduces the number of herd 
replacements and milk production and increases medical and feeding treatment costs, number of artificial inseminations, and cow culling rates (Segura-Correa and Segura-Correa, 2009; Gädicke et al., 2010). Abortion may be caused by infectious or non-infectious causes. While the infectious causes of abortion have been a main focus of attention, non-infectious abortion is more common in endemic situations. Different causative factors, including genetic, maternal, and external factors, have been reported for abortion in cows. These include the inseminating bull, twin pregnancy, parity cow, milk production, the serum progesterone level after conception, heat stress, and the season. Abortion may result in the retention of fetal membranes and the evolution of endometritis, which subsequently reduces reproductive performance in cattle. The fertility of cows plays an important role in the productivity of cattle herds. Abortion is one of the major sources of decreased fertility, and this produces adverse economic effects for cattle farms. On the other hand, a lengthy postpartum interval in cattle with abortion can lead to increased culling (Lee and Kim, 2007).

Stillbirth parturition is defined as calves that are either born dead, and or die within 24 hours of calving after at least 260 days of gestation (Berglund et al., 2003; Gundelach et al., 2009; Atashi, 2011; ElTarabany, 2015). Genetic, management, and environmental factors have varying degrees of influence on the rate of stillbirth. Stillbirth parturition does constitute great financial losses to the cattle producer in different ways. Stillbirth decreases the number of calves for sale and replacement and is associated with increased placental retention, metritis, and has a considerable negative effect on conception rate, lactation performance, and longevity, involuntary culling, and longer calving intervals (Bicalho et al., 2008; Atashi, 2011). Cows experiencing stillbirth are more probably to be culled or die during lactation (Bicalho et al., 2007).

Identifying the risk factors associated with abortion and stillbirth can help to optimize the reproductive performance of the herd. In addition, estimating the effects of abortion and stillbirth on reproductive efficiency and survival has great importance to evaluate the cost benefits of diagnosis, treatments, and prevention efforts (Ribeiro et al., 2013). Therefore, this study aimed to identify the factors that affect the occurrence of abortion and stillbirth as well as to investigate their effects on the subsequent reproductive performances of the Friesian and Baladi cows and their crossbred under Egyptian conditions. 


\section{MATERIALS AND METHODS}

This study was performed on two experimental stations belonged to Animal Production Research Institute, Ministry of Agriculture, Egypt, one of them in the east of the Nile Delta (El-Serw Station) and the other west of the Nile Delta (El-Qarada Station). These stations are characterized by a recording system for all data related to animals. These areas are considered to be densely populated in cattle breeding. Both stations are similar in air temperature, relative humidity. Average minimum and maximum air temperatures were 8.3 and $19.6^{\circ} \mathrm{C}$ in the winter season, 15.5 and $28.8^{\circ} \mathrm{C}$ in the spring season, 20.1 and $31.6^{\circ} \mathrm{C}$ in the summer season, and 13.8 and 24.4 ${ }^{\circ} \mathrm{C}$ in the autumn season, respectively. Data were collected from 2098 records concerning cows from 3 breeds (1049 Friesian, 607 Baladi, and 442 their crossbred), during the period from January 2009 until December 2019.

\section{Animals and management practices}

Cows were housed in open sheds and fed traditional summer ration consisted of concentrate feed mixture (CFM), berseem hay, rice straw and corn silage and traditional winter ration consisted of concentrate feed mixture, fresh berseem and rice straw. Cows were fed to cover the recommended requirements according to Animal Production Research Institute Recommendation (APRI, 1997) for Friesian and Baladi cows and their crossbred. Cows were fed in groups feeding assigned according to live body weight, milk yield and reproductive status. Water and minerals salt were available for animals all the day round. Cows were milked twice times daily at 6:00 and 17:00 h. Daily milk yield was individually recorded for the lactation period. At each milking, cows were examined for symptoms of clinical mastitis.

Breed of the cow, date of the abortion or calving, calving type (normal, stillbirth, or abortion), and cow parity were recorded for all cows. Abortion is defined as the death of the fetus between 60 and 260 days of pregnancy. Stillbirth parturition is defined as calves that are either born dead and or die within 24 hours of calving after at least 260 days of gestation (Berglund et al., 2003; Gundelach et al., 2009; Atashi, 2011; ElTarabany, 2015).

\section{Reproductive performance}

The postpartum reproductive diseases were treated until recovery, pregnancy or culling. The voluntary waiting period from calving to the first artificial insemination in this study was 45 days. Estrus was detected by visual observation of cow estrus behavior each morning and afternoon by trained workers. Cows in estrus were artificially inseminated using frozen semen within 14 hours after the onset of the first spontaneously occurring estrus (according to the a.m.-p.m. rule). Days of first services, number of 
services per conception, days open, and calving interval were recorded. Pregnancy status was confirmed 60 days after artificial insemination by examining the reproductive tract and palpating the uterine contents by rectum.

\section{Statistical analysis}

All statistical procedures were performed using SAS Statistical System package V9.0 (SAS, 2002). Using a multivariable logistical regression procedure, the potential effects of cow breed and environmental risk factors such as season of abortion or calving and parity number on abortion and stillbirth rates were examined. The breed of cow was categorized as Friesian, Baladi, and crossbred. Abortion and calving seasons were categorized as spring, summer, autumn, and winter. The parity of cow was categorized as $1,2,3$, or higher.

The GLM procedure of SAS was used to determine the effect of incidence of abortion and stillbirth on different reproductive variables (days to first service, number of services to conception, days open, and calving interval) in the subsequent lactation. The model for statistical analyses included the fixed effects of calving traits and breed. Categorical variables included (three levels: normal calving, abortion, and stillbirth) and categorized breeds (three levels: Friesian, Baladi, and crossbred). The significant differences among means were tested using Duncan's Multiple Range Test (Duncan, 1955). Probability values $\leq 5 \%$ were considered significant.

\section{Risk factors affecting abortion}

\section{RESULTS AND DISCUSSION}

The overall incidence of abortion was 3.77\% (79 cases) of the total 2098 pregnant cows. This result is higher than that reported by Segura-Correa and Segura-Correa (2009) who indicated that the prevalence of abortion for beef herd managed under the extensive pasture system was $1.17 \%$. Also, Osteras $\boldsymbol{e t}$ al. (2007) reported that the incidence of abortion rate in dairy cattle is between 0.6 and $1.2 \%$. While it is less than that reported by Lee and Kim (2007) who found that the overall incidence rate of pregnancy loss was $6.9 \%$ in a population of 1,001 pregnant dairy cows. But it is within the range reported by Plasse $\boldsymbol{e t}$ al. (1998) in beef herds (0.6 to 4.5\%). According to Bagley (1999); SeguraCorrea and Segura-Correa (2009) if the abortion rate is higher than 3\% that should be of some concern and the breeder must make efforts to obtain a diagnosis. Also, the incidence of abortion may be higher than that if abortion occurs at an early stage of pregnancy where early fetal loss is not detected (pregnancy termination at less than 60 days) because the expulsion of the fetus and placenta tissue may not be seen and recorded. The difference between abortion prevalences in herds reflects differences in genetics, nutrition, management, environments between systems, and prevailing diseases in the different regions. Effective control measures for abortions require not only a 
prompt and accurate diagnosis but also an understanding of the multicausal factors involved. Khodakaram-Tafti and Ikede (2005) showed that for several reasons, it is hard to establish the causes of bovine abortion. Any disturbance in the normal physiology of gestation can lead to abortion. Thus, numerous causes, such as infectious agents, hormonal imbalance, faulty nutrition, toxins, vaccinations, physical influences, and chromosomal disturbances, can lead to abortion.

Table 1 shows that the incidence rate of abortion in Friesian cows was higher (4.19\%) when compared with Baladi and crossbred cows (3.62 and 2.94 $\%$, respectively). While the logistic regression analysis shows that the likelihood of incidence of abortion was insignificantly 1.44 times (range: 0.77 to 2.71; $P=0.252$ ) in Friesian cows and 1.24 times (range: 0.62 to $2.49 ; P=0.544$ ) in Baladi cows compared with crossbred cows. From this result, it is clear that the cow breed is not a risk factor affecting the incidence of abortion.

Table 1 shows that the incidence rate of abortion during summer was higher $(5.44 \%)$ when compared with winter, autumn, and spring $(3.60,3.55$, and $2.39 \%$, respectively). In addition, the logistic regression analysis shows that the likelihood of incidence of abortion was significantly 2.35 times (range: 1.12 to $4.92 ; P=0.024$ ) during summer compared with spring. While it is insignificantly during winter 1.52 times (range: 0.71 to $3.27 ; P=0.280$ ) and during autumn 1.50 times (range: 0.70 to $3.21 ; P=0.292$ ) compared with spring. This suggests that the environmental conditions can play an important role in the presence of pathogens and result in abortion (Segura-Correa and SeguraCorrea, 2009). This is consistent with previous studies. For example, it has been reported that the risk for pregnancy loss was increased during May to September versus October to April due to heat stress (García-Ispierto et al. 2006). Similarly, in another report, pregnancy loss was increased from June to October, and it peaked in July and September (Carpenter et al. 2006). While, there is some evidence to suggest that a very sudden increase in environmental temperature may result in abortion (heat stress causes fetal hypotension, hypoxia, and acidosis, high maternal temperature due to fever may be more important than environmentally induced heat stress). There was little evidence to support heat stress as a common cause of pregnancy loss or abortion (the bovine fetus is well protected by the amniotic fluid). Al-Samarai et al. (2012) found that the highest pregnancy loss ratio in summer $(7.49 \%)$, whereas the lowest was in winter and autumn (4.80 and 5.75\%, respectively). The significant differences between estimates may belong to high-temperature degrees which could cause heat stress and abortion in animals.

The risk of abortion was higher in older cows compared to young cows (Table 1). The incidence rate of abortion in third or higher (4.84\%) parity cows as compared to second parity (3.33\%) and first parity cows $(2.33 \%)$. Whereas, the logistic regression analysis shows that the likelihood of incidence of abortion was significantly 2.13 times (range: 1.19 to $3.83 ; P=0.011$ ) in third or 
higher parity cows as compared to first parity cows. While it is insignificantly in second parity cows 1.45 times (range: 0.69 to $3.03 ; P=0.328$ ) compared to first parity cows. This result is consistent with Lee and Kim (2007) who found that cow parity was the risk factor for pregnancy loss. The likelihood of pregnancy loss in cows with parities of one or two was decreased by 0.6 or 0.5 fold of that for the cows with a parity of three or higher, respectively $(P<0.05)$. They reported that the influence of parity on pregnancy loss is unclear. They suggested that high milk production at the third parity compared to previous parities, which mobilizes more body fat and results in severe loss of body condition might be linked to the increased pregnancy loss. Also, it is similar to the results of Thurmond $\boldsymbol{e t}$ al. (1990) who reported that pregnancy loss increased after four calvings. Similarly, Humblot (2001) showed that the frequency of embryonic mortality increased with parity $\left(1^{\text {st }}\right.$ to $3^{\text {rd }}$ parity). Santos et al. (2004) reported that pregnancy loss was $10.7 \%$ for lactating cows and $4.2 \%$ for dairy heifers. Silke $\boldsymbol{e t}$ al. (2002) recorded that milk production affects embryo loss between days 24 and 80, the embryo losses were $7 \%$ in lactating cows and 6\% approximately in heifers. Circulating progesterone concentrations decrease in high milk production of Holstein cows. During gestation, progesterone influences embryo development stimulates interferontau production and inhibits the luteolytic cascade (Shahneh $\boldsymbol{e t}$ al., 2008). Chegini et al. (2016) indicated that the incidence of abortion and retained placenta of primiparous cows is lower. This is probably due to the uterus of a primiparous cow has steadier ligaments and thus better able to keep the foetus and expel the placenta after parturition.

Table 1. Odds ratios and $95 \%$ confidence intervals (CI) of the independent variables associated with the incidence of abortion under Egyptian conditions in the multivariable logistic regression model

\begin{tabular}{|c|c|c|c|c|c|}
\hline Variable & No & Abortion (\%) & Odd ratio & $95 \% \mathrm{CI}$ & $P$-value \\
\hline \multicolumn{6}{|l|}{ Cow breed } \\
\hline Friesian & 1049 & $44(4.19 \%)$ & 1.44 & $(0.77-2.71)$ & 0.252 \\
\hline Baladi & 607 & $22(3.62 \%)$ & 1.24 & $(0.62-2.49)$ & 0.544 \\
\hline Crossbred & 442 & $13(2.94 \%)$ & 1 & & \\
\hline \multicolumn{6}{|l|}{ Season of abortion } \\
\hline Winter & 583 & $21(3.60 \%)$ & 1.52 & $(0.71-3.27)$ & 0.280 \\
\hline Spring & 418 & $10(2.39 \%)$ & 1 & & \\
\hline Summer & 478 & $26(5.44 \%)$ & 2.35 & $(1.12-4.92)$ & 0.024 \\
\hline Autumn & 619 & $22(3.55 \%)$ & 1.50 & $(0.70-3.21)$ & 0.292 \\
\hline \multicolumn{6}{|l|}{ Parity number } \\
\hline 1 & 644 & $15(2.33 \%)$ & $\mathbf{1}$ & & \\
\hline 2 & 420 & $14(3.33 \%)$ & 1.45 & $(0.69-3.03)$ & 0.328 \\
\hline$\geq \mathbf{3}$ & 1034 & $50(4.84 \%)$ & 2.13 & $(1.19-3.83)$ & 0.011 \\
\hline
\end{tabular}

\section{Risk factors affecting stillbirth}

The overall rate of live calves was $94.95 \%$ (1917 calvings) and stillbirth was $5.05 \%$ (102 calvings) from a total number of 2019 calvings. This result agrees with that reported by Atashi (2011) who found in total 12283 calvings 
were 94\% (11550) live calves and 6\% (733) stillbirths. Also, Juozaitiene et al. (2017) estimated that the stillbirth parturition rate was 5.37\%. But it is less than stated by Berglund $\boldsymbol{e t}$ al. (2003) who reported that the level of stillbirths in first-calving Swedish Holstein cows was $10.3 \%$. The overall incidence of calf stillbirth in Holstein cows of Iran was reported to be $4.9 \%$ and varied among herds from 2.9 to $9.8 \%$ (Hossein-Zadeh et al., 2008). The difficulty of calving or dystocia has been implicated as the major cause of stillbirths (Lombard $\boldsymbol{e t}$ al., 2007; Gundelach et al., 2009). The results of some studies (Berglund $\boldsymbol{e t}$ al., 2003; Atashi, 2011) shown that there is a significant association between calving difficulty and the incidence of stillbirth. Incompatibility between dam size and calf size, as well as pelvic and vulvar conformation, are factors likely to have an important impact on calving difficulty. Furthermore, calving difficulty increases the probability of stillbirth due mainly to trauma and anoxia (a lack of oxygen). Juozaitiene et al. (2017) found that the stillbirth rate was 11.2 times higher in cattle with severely difficult calving compared to cattle without calving difficulties or minor calving difficulties $(\mathrm{P}<0.0001)$. Johanson and Berger (2003) found that difficult calving tended to result in perinatal mortality 2.7 times more than unassisted calving, while Berry $\boldsymbol{e t}$ al. (2007) estimated an eight times greater likelihood of stillbirth when assistance at births was required. Lombard et al. (2007) indicated that the incidence of stillbirth was 3.2, 8.4, and $37.2 \%$ for calves born with no dystocia, mild dystocia, and severe dystocia, respectively. Berglund et al. (2003) indicated that prolonged but not necessarily difficult calving caused by, e.g. weak labor, might be a risk factor for calf mortality. For stillborn calves, the time interval from onset of labor until calving was completed was approximately twice as long as for liveborn calves. Also, one of the reasons for the occurrence of stillbirth the Genetic defects, e.g. a larger number of sublethal genes, which lower the viability at birth and might be one explanation of the increased stillbirth rates. Some examples of recently identified genetic defects in the Holstein breed are Complex Vertebral Malformation (CVM), bulldog syndrome, and Bovine Leukocyte Adhesion Deficiency (BLAD). Also, Segura-Correa and Segura-Correa (2009) suggested that stillbirth may be due to poor foetal viability, placental dysfunction or prolonged duration of calving.

Table 2 shows that the incidence rate of stillbirth was higher in Friesian cows $(7.06 \%)$ as compared to Baladi cows $(3.42 \%)$ and crossbred cows $(2.53 \%)$. Whereas, the logistic regression analysis shows that the likelihood of incidence of stillbirth was significantly 2.89 times (range: 1.52 to 5.51; $P=0.001)$ in Friesian cows as compared to crossbred cows. While it is insignificantly in Baladi cows 1.35 times (range: 0.64 to $2.84 ; P=0.436$ ) compared to crossbred cows. This may be due to the lower average birth weight of the crossbred $(28.7 \mathrm{~kg})$ and Baladi $(22.5 \mathrm{~kg})$ calves compared to the average birth weight of the Friesian calves $(33.6 \mathrm{~kg})$, which lead to the non-high incidence of dystocia in the crossbred and Baladi cows compared to the Friesian 
cows. This is consistent with some studies that indicated that there are differences between different breeds in the stillbirth rate, such as El-Tarabany (2015) who found the pure Brown Swiss heifers had a significantly $(P<0.05)$ lower incidence of stillbirth $(4.5 \%)$, compared with pure Holstein heifers (15.4\%). Dairy producers reported fewer stillbirths when Jersey and Brown Swiss bulls were utilized in crossbreeding programs with Holstein cows (Yao et al. 2014).

Table 2 shows that the incidence rate of stillbirth during summer was higher $(8.63 \%)$ when compared with winter, spring, and autumn $(3.56,4.66$, and $4.02 \%$, respectively). In addition, the logistic regression analysis shows that the likelihood of incidence of stillbirth was significantly 2.56 times (range: 1.47 to $4.45 ; P=0.001$ ) during summer compared with winter. While it is insignificantly during spring 1.32 times (range: 0.70 to $2.51 ; P=0.391$ ) and during autumn 1.14 times (range: 0.62 to $2.08 ; P=0.681$ ) compared with winter.

Table 2 indicates that the first parity recorded the highest rate of stillbirth (7.95\%), then followed it the second parity $(5.67 \%)$ and then the third parity (2.95\%). The logistic regression analysis shows that the likelihood of incidence of stillbirth was significantly 2.84 times (range: 1.78 to $4.55 ; \mathrm{P}<0.001$ ) in the first parity cows as compared to the third or higher parity cows. Also, it was significantly in the second parity cows 1.98 times (range: 1.13 to 3.46; $P=0.017)$ compared to third or higher parity cows. This is consistent with Juozaitiene et al. (2017), who recorded that the stillbirth rates were higher in cows of the first parity compared to the older ones, where stillbirth in cows of the first parity was $6.5 \%$, whereas only $4.5 \%$ and $4.7 \%$ of stillbirth cases were recorded in cows of parities 2 and 3, respectively. Also, Atashi (2011) has shown that to be a more important problem in the first parity calving compared to second calving or more. Stillbirth frequency in the second and later parities drops to half or less than that for the first parity. He indicated that this is an incidence in heifers because of a disproportion between the size of the calf and the pelvic area, which causes difficult calving and increases stillbirth parturition incidence. Also, Meyer et al. (2001) have reported that the stillbirth rate was from 9.5 to $13.2 \%$ in primiparous and 5.0 to $6.6 \%$ in multiparous Holstein cows in the United States. Segura-Correa and Segura-Correa (2009) found that stillbirth is a different trait in younger and older cows where the likelihood of stillbirth was approximately 3 times as high in primiparous compared with multiparous cows. They reported that sheep research has shown that first parity animals had smaller and less efficient placentas resulting in less viable lambs than those of older sheep. Chegini et al. (2016) demonstrated that primiparous cows had a higher incidence of stillbirth. This is probably due to the fact primiparous cows have smaller pelvic dimensions that can lead to more stillbirth. López de Maturana et al. (2007) noticed that it is important to keep calving difficulties under control, especially in primiparous cows and to escape reduction of profitability in herds. 
Table 2. Odds ratios and $95 \%$ confidence intervals (CI) of the independent variables associated with the incidence of stillbirth under Egyptian conditions in the multivariable logistic regression model

\begin{tabular}{|c|c|c|c|c|c|}
\hline Variable & No & Stillbirth (\%) & Odd ratio & $95 \% \mathrm{CI}$ & $P$-value \\
\hline \multicolumn{6}{|l|}{ Cow breed } \\
\hline Friesian & 1005 & $71(7.06 \%)$ & 2.89 & $(1.52-5.51)$ & 0.001 \\
\hline Baladi & 585 & $20(3.42 \%)$ & 1.35 & $(0.64-2.84)$ & 0.436 \\
\hline Crossbred & 429 & $11(2.56 \%)$ & 1 & & \\
\hline \multicolumn{6}{|l|}{ Season of calving } \\
\hline Winter & 562 & $20(3.56 \%)$ & 1 & & \\
\hline Spring & 408 & $19(4.66 \%)$ & 1.32 & $(0.70-2.51)$ & 0.391 \\
\hline Summer & 452 & $39(8.63 \%)$ & 2.56 & $(1.47-4.45)$ & 0.001 \\
\hline Autumn & 597 & $24(4.02 \%)$ & 1.14 & $(0.62-2.08)$ & 0.681 \\
\hline \multicolumn{6}{|l|}{ Parity number } \\
\hline 1 & 629 & $50(7.95 \%)$ & 2.84 & $(1.78-4.55)$ & $<0.001$ \\
\hline 2 & 406 & $23(5.67 \%)$ & 1.98 & $(1.13-3.46)$ & 0.017 \\
\hline$\geq \mathbf{3}$ & 984 & $29(2.95 \%)$ & 1 & & \\
\hline
\end{tabular}

\section{Effect of abortion and stillbirth on the subsequent reproductive performance}

Table 3 shows that several measures of fertility (days to the first service, number of services to conception, days open, and calving interval) were affected by the occurrence of abortion or stillbirth in differwnt breeds. This is consistent with Senger, 2003 and Eaglen et al. (2011) who reported that parturition in cattle is a complex process that is triggered by the fetus and managed by a cascade of hormonal actions and physiological changes. When complications occur during parturition, this has a potential effect on normal bodily functions, where this leads to the following impaired reproductive performance.

Data in Table (3) shown that days of first services were significantly $(P<0.05)$ affected by the incidence of abortion or stillbirth. Results revealed that days to first services were significantly increased $(P<0.05)$ in cows experiencing abortion or stillbirth, where required $83.9 \pm 19.1$ or $126.5 \pm 23.9$ days, respectively compared with the normal calving (75.1 \pm 17.2 days). The negative effect on the days of the first service was most pronounced when stillbirth occurred by delaying the first service for 51.4 days compared to the delaying of service for 8.8 days when the abortion occurred. Difficult calving and stillbirth are acute stressors, affecting the function of the hypothalamic, leading to delay of the surge of luteinizing hormone $(\mathrm{LH})$ and abnormal ovarian function (Dobson et al. 2001). Schrick et al. (2001) reported that, inflammation stimulates the immune system resulting in the release of cytokines which may inhibit the action of FSH on LH receptor formation in granulosa cells and inhibit FSH-induced cAMP production. Also, they indicated that cytokines, 
released following endotoxin challenge, block the pulsatile secretion of LH but not FSH through alterations in nitric oxide production to inhibit GnRH. Lee and Kim (2007) found that the overall mean interval from pregnancy loss to the first service in dairy cows was $63.4 \pm 5.2$ days. The interval from pregnancy loss to the first service was longer $(P<0.01)$ for the cows with pregnancy loss during the third trimester $(87.5 \pm 11.6$ days $)$ than for the cows with pregnancy loss during the first trimester (44.9 \pm 7.2 days) and second trimester (54.6 \pm 5.0 days). Also, Lee and Kim (2007) found that following pregnancy loss, the mean incidence rate of endometritis was $23.2 \%$ and this rate was higher $(P<0.05)$ for the dairy cattle with pregnancy loss during the third trimester (45.5\%) than for the cattle with pregnancy loss during the first $(7.7 \%)$ and second trimesters $(14.7 \%)$. This can reflect the more delayed uterine involution and increased incidence of the retained placenta associated with pregnancy loss in the third trimester, as compared to the earlier trimesters of gestation. Ribeiro et al. (2013) observed that cows with no clinical uterine disease tended to be more likely to be a resumption of estrous cyclicity by day 49 postpartum than those with uterine diseases, particularly those with metritis or metritis and clinical endometritis combined. Sheldon et al. (2009) indicated that after parturition, almost all cows have a uterus contaminated by a wide range of bacteria, and the development of uterine diseases depends on the ability of the local immune system to control bacterial growth. It is thought that bacteria and products of inflammation from the uterus influence ovarian follicular activity in early lactation, which compromises resumption of ovulation.

Data in Table (3) showed that the number of services per conception was significantly $(P<0.05)$ affected by the incidence of abortion or stillbirth. The number of services per conception was significantly increased $(P<0.05)$ in cows experiencing abortion or stillbirth $(2.7 \pm 1.1$ and $4.9 \pm 1.3$ services, respectively) compared with the normal calving (1.8 \pm 0.9 services). These results agreed with that found by El-Tarabany (2015) who found that the average number of inseminations per parturition (artificial insemination) was increased from 3.2 after normal calving to 4.1 after abrtion and to 5.3 after stillbirths in pure Holstein cows. Ribeiro et al. (2013) reported that diseases that affected the uterus had the greatest effect on pregnancy per artificial insemination. Indeed, metritis and clinical endometritis had additive effects, reducing pregnancy per artificial insemination and resulting in the greatest pregnancy loss. Also, uterine inflammation is likely to damage the endometrium and the uterine glands, which are critical for proper establishment and maintenance of pregnancy. Also, a comprehensive study with 2,793 cows demonstrated that clinical endometritis affected $21.2 \%$ of the population and reduced reproductive efficiency during the breeding season (McDougall $\boldsymbol{e t}$ al., 2007). 
Table 3. The effects of abortion and stillbirth on the subsequent reproduction performance

\begin{tabular}{|c|c|c|c|}
\hline Trait & Normal calving & Abortion & Stillbirth \\
\hline \multicolumn{4}{|l|}{ Days to first service (day) } \\
\hline Friesian & $84.9 \pm 14.1^{b}$ & $90.3 \pm 20.8^{b}$ & $140.8 \pm 9.3^{\mathrm{a}}$ \\
\hline Baladi & $63.1 \pm 15.4^{b}$ & $71.1 \pm 10.1^{b}$ & $89.5 \pm 9.9^{a}$ \\
\hline Crossbred & $73.1 \pm 12.8^{b}$ & $82.1 \pm 14.6^{b}$ & $102.6 \pm 13.2^{\mathrm{a}}$ \\
\hline Overall mean & $75.1 \pm 17.2^{\mathrm{c}}$ & $83.9 \pm 19.1^{b}$ & $126.5 \pm 23.9^{a}$ \\
\hline \multicolumn{4}{|l|}{$\begin{array}{l}\text { Number of services to } \\
\text { conception }\end{array}$} \\
\hline Friesian & $2.1 \pm 0.9^{c}$ & $3.0 \pm 1.1^{b}$ & $5.2 \pm 1.1^{\mathrm{a}}$ \\
\hline Baladi & $1.5 \pm 0.5^{\mathrm{c}}$ & $2.0 \pm 0.9^{b}$ & $3.9 \pm 1.5^{\mathrm{a}}$ \\
\hline Crossbred & $1.7 \pm 1.1^{\mathrm{b}}$ & $2.7 \pm 1.3^{b}$ & $4.6 \pm 1.1^{\mathrm{a}}$ \\
\hline Overall mean & $1.8 \pm 0.9^{c}$ & $2.7 \pm 1.1^{b}$ & $4.9 \pm 1.3^{\mathrm{a}}$ \\
\hline \multicolumn{4}{|l|}{ Days open (day) } \\
\hline Friesian & $122.7 \pm 24.5^{\mathrm{c}}$ & $150.8 \pm 47.7^{b}$ & $194.2 \pm 18.00^{\mathrm{a}}$ \\
\hline Baladi & $92.1 \pm 35.7^{b}$ & $112.8 \pm 29.4^{b}$ & $148.4 \pm 54.9^{\mathrm{a}}$ \\
\hline Crossbred & $108.2 \pm 46.9^{b}$ & $138.9 \pm 48.7^{\mathrm{ab}}$ & $172.2 \pm 39.8^{\mathrm{a}}$ \\
\hline Overall mean & $109.4 \pm 36.7^{\mathrm{c}}$ & $138.9 \pm 45.8^{b}$ & $182.9 \pm 35.0^{\mathrm{a}}$ \\
\hline \multicolumn{4}{|l|}{ Calving interval (day) } \\
\hline Friesian & $412.4 \pm 46.9^{c}$ & $442.5 \pm 49.8^{b}$ & $491.9 \pm 20.9^{a}$ \\
\hline Baladi & $388.4 \pm 56.0^{b}$ & $409.8 \pm 43.5^{\mathrm{ab}}$ & $439.6 \pm 57.3^{a}$ \\
\hline Crossbred & $406.7 \pm 60.8^{\mathrm{a}}$ & $434.4 \pm 44.0^{a}$ & $459.4 \pm 46.5^{\mathrm{a}}$ \\
\hline Overall mean & $403.2 \pm 54.3^{\mathrm{c}}$ & $432.7 \pm 48.1^{b}$ & $478.0 \pm 39.2^{a}$ \\
\hline
\end{tabular}

a, b, c Means in the same row within the same factor with different superscripts are significantly different $(\mathrm{P}<0.05)$.

Table (3) illustrated that number of days open of cows was significantly $(P<0.05)$ affected by the occurrence of the abortion or stillbirth. Cows experiencing abortion or stillbirth had $138.9 \pm 45.8$ and $182.9 \pm 35.0$ days, respectively days open than normal calving (109.4 \pm 36.7 days). This is consistent with El-Tarabany (2015) who found that pure Holstein cattle experiencing stillbirths and abortions had significantly longer days open (198 and 151 days, respectively), compared with the normal calving (149 days). The postpartum disorders were increased in cattle experiencing stillbirths such as retained placenta, prolapsed uterus, metritis, and displaced abomasums (Correa et al. 1993).

Lee and Kim (2007) found that the overall mean interval from pregnancy loss to conception was $101.8 \pm 10.8$ days. This interval did not differ according to time of pregnancy loss. Ribeiro et al. (2013) reported that pregnancies per artificial insemination on day 30 and 65 after insemination were greater $(P<0.01)$ in cows with no uterine disease than those with the uterine disease. An additive effect of decreasing fertility was observed when cows were diagnosed with both metritis and clinical endometritis. Where a large portion of this decline in fertility caused by 
uterine diseases was because of increased risk of pregnancy loss between 30 and 65 days of gestation (9.1 vs. $21.9 \%$ ).

The cows experiencing abortion or stillbirth had significantly longer calving intervals ( $432.7 \pm 48.1$ or $478.0 \pm 39.2$ days, respectively), compared with the normal calving $(403.2 \pm 54.3$ days). This result consistent with that reported by El-Tarabany (2015) who found that pure Holstein cows experiencing stillbirths and abortions had significantly longer calving intervals (475 and 427 days, respectively), compared with the normal calving (381 days).

\section{CONCLUSIONS}

In conclusion, this study revealed that the cow breed was a risk factor for the incidence of stillbirth. While the season and cow parity were a risk factor for the incidence of abortion and stillbirth. The study also showed that abortion and stillbirth had negative effects on the subsequent reproductive performance of the cow. Abortion and stillbirth significantly increased calving interval and number of services to conception compared with the normal calving. The effect of stillbirth was more negative on reproductive performance than abortion.

\section{REFERENCES}

Al-Samarai, F. R. ; Y. K. Abdulrahman ; Wafaa I. Ibrahim and A. M. Al-Nedawi (2012). Effect of some environmental factors on abortion and offspring sex ratio in Holstein cows in Iraq. International Joubnal of Science and Nature, 3(2): 361-365.

APRI. (1997). Animal Nutrition Scientifically and Practically. 1st Ed. Animal Production Research Institute, Agricultural Research Center, Ministry of Agriculture, Dokki, Giza, Egypt (In Arabic).

Atashi, H. (2011). Factors affecting stillbirth and effects of stillbirth on subsequent lactation performance in a Holstein dairy herd in Isfahan. Iranian Journal of Veterinary Research, Shiraz University, 12 (1): 24-30.

Bagley, C.V. (1999). Abortion in cattle. Utah State University Extension. Animal health Fact sheet.

Berglund, B. ; L. Steinbock and M. Elvander (2003). Causes of stillbirth and time of death in Swedish Holstein calves examined post mortem. Acta veterinaria Scandinavica, 44(3-4): 111-120.

Berry, D.P. ; J.M. Lee ; K.A. Macdonald and J.R. Roche (2007). Body condition score and body weight effects on dystocia and stillbirths and consequent effects on postcalving performance. Journal of Dairy Science, 90(9): 4201-4211. 
Bicalho, R.C. ; K.N.Galvão ; S.H. Cheong ; R.O. Gilbert ; L.D. Warnick and C.L. Guard (2007). Effect of stillbirths on dam survival and reproduction performance in Holstein dairy cows. Journal of Dairy Science, 90(6): 2797-2803.

Bicalho, R.C. ; K.N. Galvão ; L.D. Warnick and C.L. Guard (2008). Stillbirth parturition reduces milk production in Holstein cows. Preventive Veterinary Medicine, 84(1-2): 112-120.

Carpenter, T.E. ; M. Chrièl ; M.M. Andersen ; L. Wulfson ; A.M. Jensen ; H. Houe and M. Greiner (2006). An epidemiologic study of late-term abortions in dairy cattle in Denmark, July 2000August 2003. Preventive veterinary medicine, 77(3-4): 215-229.

Chegini, A. ; N.Ghavi Hossein-Zaden ; H.Hosseini-Moghadam and A.A. Shadparvar (2016). Factors affecting clinical mastitis and effects of clinical mastitis on reproductive performance of Holstein cows. Rev Med Vet., 167(5-6): 145-153.

Correa, M.T. ; H. Erb and J. Scarlett, (1993). Path analysis for seven postpartum disorders of Holstein cows. Journal of Dairy Science, 76(5): 1305-1312.

Dobson, H. ; J.E. Tebble ; R.F. Smith and W.R. Ward (2001). Is stress really all that important?. Theriogenology, 55(1): 65-73.

Duncan, D. B. (1955): Multiple rang and multiple F test. Biometrics 11: 142.

Eaglen, S.A. ; M.P. Coffey ; J.A. Woolliams ; R. Mrode and E. Wall (2011). Phenotypic effects of calving ease on the subsequent fertility and milk production of dam and calf in UK HolsteinFriesian heifers. Journal of Dairy Science, 94(11): 5413-5423.

El-Tarabany M. S. (2015). Impact of stillbirth and abortion on the subsequent fertility and productivity of Holstein, Brown Swiss and their crosses in subtropics. Tropical Animal Health and Production, 47(7): 1351-1356.

Gädicke, P. ; R.Vidal and G. Monti (2010). Economic effect of bovine abortion syndrome in commercial dairy herds in Southern Chile. Preventive Veterinary Medicine, 97(1): 9-19.

García-Ispierto, I. ; F. López-Gatius ; P. Santolaria ; J.L. Yániz ; C. Nogareda ; M. López-Béjar and F. De Rensis (2006). Relationship between heat stress during the peri-implantation period and early fetal loss in dairy cattle. Theriogenology, 65(4): 799-807.

Gundelach, Y. ; K. Essmeyer ; M.K. Teltscher and M. Hoedemaker (2009). Risk factors for perinatal mortality in dairy cattle: cow and foetal factors, calving process. Theriogenology, 71(6): 901-909. 
Hossein-Zadeh, N.G. ; A. Nejati-Javaremi ; S.R. Miraei-Ashtiani and H. Kohram (2008). An observational analysis of twin births, calf stillbirth, calf sex ratio, and abortion in Iranian Holsteins. Journal of Dairy Science, 91(11): 4198-4205.

Humblot P. (2001). Use of pregnancy specific proteins and progesterone assays to monitor pregnancy and determine the timing, frequencies and sources of embryonic mortality in ruminants. Theriogenology, 56(9): 1417-1433.

Johanson, J.M. and P.J. Berger (2003). Birth weight as a predictor of calving ease and perinatal mortality in Holstein cattle. Journal of Dairy Science, 86(11): 3745-3755.

Juozaitiene, V. ; A. Juozaitis ; A. Kardisauskas ; J. Zymantiene ; V. Zilaitis ; R. Antanaitis and M. Ruzauskas (2017). Relationship between dystocia and the lactation number, stillbirth and mastitis prevalence in dairy cows. Acta Veterinaria. Brno., 86: 345-352.

Khodakaram-Tafti, A. and B.O. Ikede (2005). A retrospective study of sporadic bovine abortions, stillbirths, and neonatal abnormalities in Atlantic Canada, from 1990 to 2001. The Canadian Veterinary Journal, 46(7): 635-637.

Lee, J.I. and I.H. Kim (2007). Pregnancy loss in dairy cows: the contributing factors, the effects on reproductive performance and the economic impact. Journal of Veterinary Science, 8(3): 283288.

Lombard, J.E. ; F.B. Garry ; S.M. Tomlinson and L.P. Garber (2007). Impacts of dystocia on health and survival of dairy calves. Journal of Dairy Science, 90(4): 1751-1760.

López de Maturana, E. ; E. Ugarte, and O. González-Recio (2007). Impact of calving ease on functional longevity and herd amortization costs in Basque Holsteins using survival analysis. Journal of Dairy Science, 90(9): 4451-4457.

McDougall, S. ; R.Macaulay and C. Compton (2007). Association between endometritis diagnosis using a novel intravaginal device and reproductive performance in dairy cattle. Animal Reproduction Science, 99(1-2): 9-23.

Meyer, C.L. ; P.J. Berger ; K.J. Koehler ; J.R. Thompson and Sattler, C. G. (2001). Phenotypic trends in incidence of stillbirth for Holsteins in the United States. Journal of Dairy Science, 84(2): 515-523.

Osteras, O. ; M.S. Gjestvang,; S. Vatn and L. Solverod (2007). Perinatal death in production animals in the Nordic countries- Incidence and cost. Acta Veterinaria Scandinavica, 49(suppl 1), S14 
Peter, A.T., (2000). Abortions in dairy cows: New insights and economic impact. Advances in Dairy Technology, 12: 233-244.

Plasse, D. ; H.Fossi and R. Hoogesteijn (1998). Mortality in Venezuelan beef cattle. World Animal Review 90.

Ribeiro, E.S. ; F.S. Lima ; L.F. Greco ; R.S. Bisinotto ; A.P. Monteiro ; M. Favoreto ; H. Ayres ; R.S. Marsola ; N. Martinez ; W.W. Thatcher and J.E. Santos (2013). Prevalence of periparturient diseases and effects on fertility of seasonally calving grazing dairy cows supplemented with concentrates. Journal of Dairy Science, 96(9): 5682-5697.

Santos, J.E. ; W.W. Thatcher ; R.C. Chebel ; R.L.Cerri and K.N. Galvão (2004). The effect of embryonic death rates in cattle on the efficacy of estrus synchronization programs. Animal Reproduction Science, 82-83: 513-535.

SAS, (2002): User's Guide: Statistics, Version 9.0 Edition. SAS Institute Inc., Cary, NC, USA.

Schrick, F.N. ; M.E. Hockett ; A.M. Saxton ; M.J. Lewis ; H.H. Dowlen and S.P. Oliver (2001). Influence of subclinical mastitis during early lactation on reproductive parameters. Journal of Dairy Science, 84(6): 1407-1412.

Segura-Correa, J. C. and V. M. Segura-Correa (2009). Prevalence of abortion and stillbirth in a beef cattle system in Southeastern Mexico. Tropical Animal Health and Production, 41(8): 1773-1778.

Senger, P.L. (2003). Pathways to Pregnancy and Parturition. 2nd rev.ed. Current Conceptions Inc., Pullman, WA.

Shahneh, A. Z. (2008). The Effect of GnRH injection on plasma progesterone concentrations, conception rate and ovulation rate in Iranian Holstein cows. J. Anim. Vet., Advances, 7(9):1137-1141.

Sheldon, I.M. ; J. Cronin ; L. Goetze ; G. Donofrio and H.J. Schuberth (2009). Defining postpartum uterine disease and the mechanisms of infection and immunity in the female reproductive tract in cattle. Biology of Reproduction, 81(6): 1025-1032.

Silke, V. ; M.G. Diskin ; D.A. Kenny ; M.P. Boland ; P. Dillon ; J.F. Mee and J.M. Sreenan (2002). Extent, pattern and factors associated with late embryonic loss in dairy cows. Animal Reproduction Science, 71(1-2): 1-12.

Thurmond, M.C. ; J.P. Picanso, and C.M. Jameson (1990). Considerations for use of descriptive epidemiology to investigate fetal loss in dairy cows. Journal of the American Veterinary Medical Association, 197(10): 1305-1312. 
Yao, C. ; K.A. Weigel and J.B.Cole (2014). Short communication: genetic evaluation of stillbirth in US Brown Swiss and Jersey cattle. Journal of Dairy Science, 97(4): 2474-2480.

العوامل المؤثرة علي الإجهاض وولادة جنين نافق وتاثيرهما علي الأداء التناسلي :ألي

\section{التالي للأبقار تحت الظروف المصرية \\ ممدوح علي السيد علي و صفاء صلاح سند}

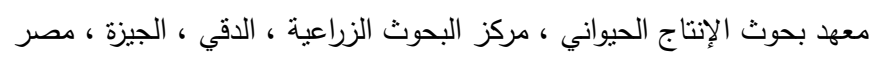

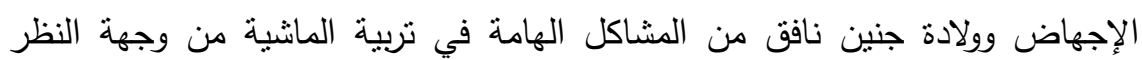

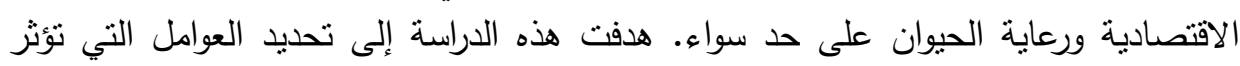

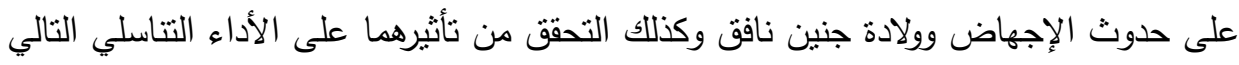

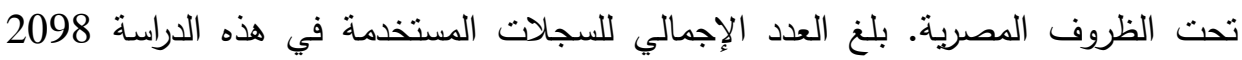

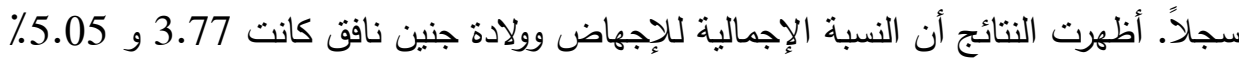

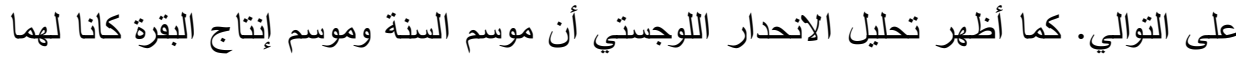

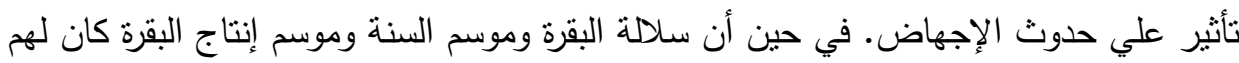

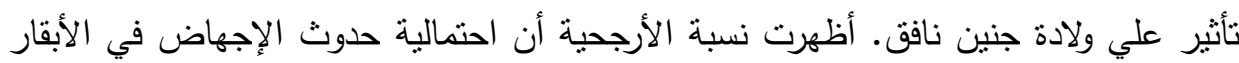

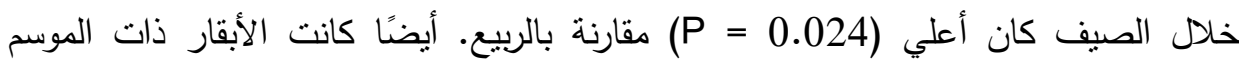

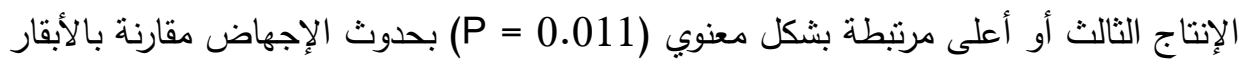

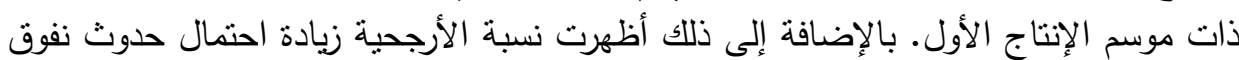

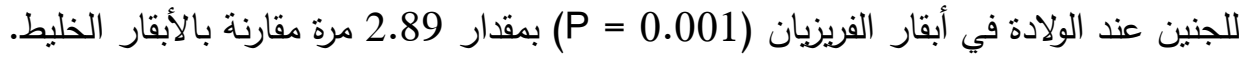

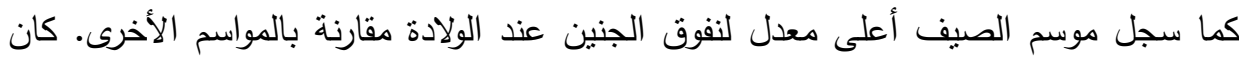

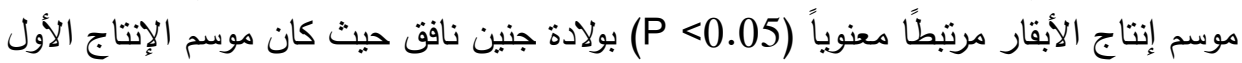

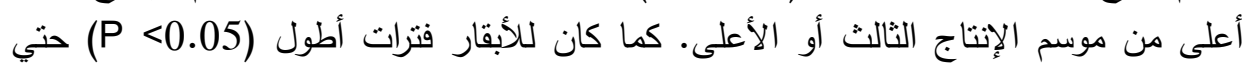

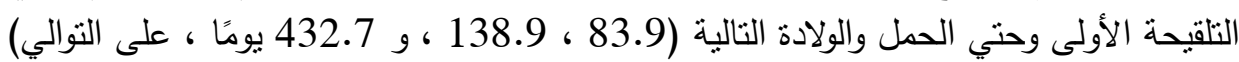

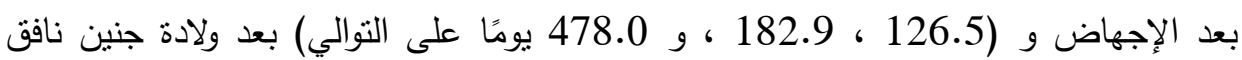



